\title{
Personality Analysis Based on Dise Test IAIN Bukittinggi Students
}

\author{
Sri Hartati ${ }^{1}$, M. Isnando Tamrin ${ }^{2}$, Kori Lilie Muslim ${ }^{3}$, Mardeni $^{4}$ \\ \{Virgo.gir12684@gmail.com¹, Bang.is1983@gmail.com², liliemuslimkori@gmail.com³, \\ denimardenideni@gmail.com ${ }^{4}$ \} \\ Institut Agama Islam Negeri (IAIN) Bukittinggi, Indonesia ${ }^{1,2,3}$ \\ SMAN 1 BASO Agam Bukittinggi, Indonesia ${ }^{4}$
}

\begin{abstract}
Personality is the overall way an individual reacts and interacts with other individuals. Personality grows and develops human life. There are various tools in measuring personality, one of which is a psychological test. In many psychological tests discuss personality tests, one of which is to find out the personality profile or what is called DISC. In learning process students tend to be passive and lackability to communicate with others. Students also oftenstress not able to manage the time in learning process. In making group assignments not all group members are responsible for completing the task. The purpose of this study to look at student personality based on the DISC test. The method this research is quantitative descriptive. The population in this study was BK Study Program for students class of 2017. The sampling technique was random sampling so that the sample in this study was 67 people. The research instrument was the DISC test.The results showed that in everyday situations there was not a single student with a Leader personality, whereas there were 2 people who had a Leader personality and in a problem situation there were 3 people who had a Leader personality. In everyday situations there are 16 people who have Influence personalities, there are 14 people with Influence personalities, and the problem situations there are 24 people who have Influence personalities. In everyday situations there are 32 people with Steadiness personalities, 28 people who have Steadiness personalities and there are 19 people who have Steadiness personalities in a state of trouble. In everyday situations there are 18 people who have Steadiness personalities, 23 people who have Compliance personalities and 21 people who have Compliance personalities in problem situations.
\end{abstract}

Keywords. Personality, Analysis, DISC test, Students

\section{Introduction}

Humans are the most perfect creatures of God, because they are equipped with reason and mind in acting. Humans as social beings cannot live alone and need the existence of others. In carrying out social interactions, each human displays a different personality.Personality is the whole way an individual reacts and interacts with other individuals. Personalities are most often described in terms of measurable traits that can be shown by someone. Besides, personality is often interpreted as features that stand out in individuals.[1] 
Personalitydevelops throughout human life, especially from birth and Personality formation must be carried out continuously and maintained so that it becomes mature and may not change again.[2]

Factors that affect a person's personality grouped into two factors: internal and external factors. Internal factors that originate from within him/her self, these internal usually genetic or innate. Genetic factors means that innate and the offspring of one of the traits owned by one of his/her parents or it could be a combination or combination of the characteristics of both parents. External factors are factors that come from outside the person. This external factor is usually an influence that comes from a person's environment starting from the smallest environment namely family, friends, neighbors to the influence of various audio-visual media.[3]

Personality is one of the factors that influence human behavior. The American Psychological Association (APA) suggests that personality refers to individual differences in terms of characteristic patterns of thinking, feeling, and behaving.[4]

Personality is a complex and dynamic unity of physical and psychological systems in the individual about how the individual sees, thinks, acts, and adapts to his environment so that it will appear in his behavior that unique and different from others.[5]In this study the personality seen how the personality of students when the learning process takes place.

Many factors affect student behavior during in learningprocess, both internal and external factors. One internal factor that influences student behavior is personality. One way to find out individual competencies and in order to help solve individual problems both regarding personal, learning, social problems, can use psychological tests.[6] There are many types of tests in psychological tests where the use of these tests is tailored to the needs, one of which is a personality test.

There are various personality test, one of which is the DISC test. One of them is the DISC test. DISC is a measure of individual personality at work created by John Geier\&Doroty Downey in 1970 by adopting DISC theory William Moulton Marson in his bookThe Emotion of normal People, the DISC Personality Model. DISC tool is a psychometric tool that is made to measure a person's behavior and how a person reacts in certain situations.[7]

DISC measures personality, more precisely work behavior. Everything that is learned in DISC is all observable. This instrument provides a description of the typesomeone who can predict the tendency of behavior in the future, which is obtained by evaluating the main personality factors that exist in a person.[8]

IAIN Bukittinggi is one of the Islamic State universitiy in West Sumatra. Besides that, IAIN Bukittinggi is also one of the university that has a lot of enthusiasts. IAIN Bukittinggi consists of several faculties, one of which is the faculty of Tarbiyah and TeacherTraining (FTIK). FTIK has several study programs and the most students guidance and counseling study programs.

In terms of the development of developmental tasks at the age of students is the establishment of a life stand in other words the stabilization is intended to further test the establishment of life and prepare themselves with the skills and abilities needed to realize the life stance they have chosen.

The results of observations during semestershow that in learningprocess students more likely to be passive, have less initiative in learning, more easily influenced by the environment. This is one of the obstacles in the learning process that affects the learning outcomes obtained.

Based on the results of the interview it can be concluded that students tend to be passive and lack initiative in learning processand to lack of communication skills with others. Students also not able to manage the time then In making group assignments not all group members are 
responsible for completing the task.Based on the DISC personality classification, each individual has a different personality style, as well as students of the guidance and counseling study program at IAIN Bukittinggi also have different personality types. So that personality can influence students in the learning process. The purpose of this research to look at the images of the occurrence of student based on DISC tests so that the problem in lecturing can be minimized.

\section{Research Methodology}

Based on the formulation of the problems that have been raised at the beginning, this research is a quantitative descriptive study in which this research aims to accumulate basic data in a descriptive manner solely not need to look for or explain the relationship, test hypotheses, make predictions or obtain meaning and implications, although which aims to find these things can also include descriptive methods.[9]In this study students were given DISC test then processed the data after it was analyzed. The subjects in this study were BK semester III students in the 2018/2019 odd school year totaling 67 people.

Table 1. Test Result Disc

\begin{tabular}{lcccc}
\hline \multicolumn{1}{c}{ Type } & Daily & Original & $\begin{array}{l}\text { Situation } \\
\text { When faced with }\end{array}$ & a problem \\
\hline Leader (pemimpin) & 0 & 2 & 3 \\
Influence (mempengaruhi) & 16 & 14 & 24 \\
Steadiness (stabil) & 32 & 28 & 19 \\
Compliance (analisa ) & 18 & 23 & 21 \\
\hline
\end{tabular}

Based on the table above it can be seen that in everyday situations there are no students who have the type of Leader for the original personality only 2 students and for situations in dealing with problems only amount to 3 people.For Influence type there are 16 students in everyday situations, 14 students for original personalities while for situations in dealing with problems there are 24 students.

Personality Steadiness there are 32 students in everyday situations, 28 students for original personality and 19 students for situations in facing problems. While Compliance personality there are 18 people for everyday situations, 23 students for original personalities and 21 students in situations facing problems.

\section{Discussion}

DISC is an instrument that bases measurements on observable human behavior. Through history and previous developments scientists and researchers have observed the similarity of basic human behavior, which is currently DISC developed to assist individuals in maximizing both their personal potential and in managing potential sources human power. DISC is a noncritical tool for understanding the type of one's behavior. DISC is designed to help individuals explore their personalitiy and types of behavior so they can better understand themselves and others.[8] DISC is usually used to get a picture of the dynamics of one's personality and to measure and predict behavioral tendencies based on personality.[3]In this study, researchers 
measured the personality of students and what types of personality are dominantly owned by students to be able to analyze the causes of problems owned by students in the learning process. There are 4 personality types of DISC, namely:

\subsection{Leader}

From the above results it's very clear that only 2 students have Leader personality and that personality is not seen in everyday situations, but when students experience problems there are 3 people who have Leader personality. It is clear that one of the problems in the learning process is due to the lack of a student's sense of responsibility towards the task, less like a challenge, and unable to take authority. In line with that theory explains that people who have a Leader personality tend to have the desire to achieve results quickly, like challenges and a new field and be able to take authority. Then the person with a Leaderpersonality has a comfortable feeling in an environment filled with power and authority towards pleasure to improve individual achievement. In addition, individuals with Leader personalities are also responsible and do not want to be controlled by others and have comfort while being able to control the environment. They are able to work well when they are not being watched. Besides that they have good ideas, this makes them in control and make decisions quickly.[10]

\subsection{Influence}

From the results of the study there were 14 students who had influenza personalities, where students were able to work in groups or teams so that when students get lecture assignments as a group they are able to complete well. Whereas in everyday situations there are 16 students with influenza personalities, so that the personality that students have is able to be applied in daily life, there are 24 students who have influenza personality when facing problems, this shows that more students are able to interact with groups even though they have problems both individual problems and group problems. The theory explains that someone who has influenza personality is an individual who has behavior that tends to be fast, he prefers to work in groups or teams in doing assignments. Students who have influenza personality will be able to work together when they like to entertain others, have influence and are good at taking other people's hearts. To increase relations he is very happy to associate with a community or a group. Influence people really enjoy connecting with others and are able to make a good impression, speak loudly and are able to create a positive and enthusiastic environment. Doing coaching and counseling is something they like.[10]

\subsection{Steadiness}

The results of the study showed that there were 28 students with Steadiness personality, this meant that the students were able to complete their lecture assignments to completion and were oriented to speed. Whereas in everyday situations there are 32 students with Steadiness personality, which means students are able to create harmony in their places such as campuses and others and 19 students with Steadiness personalities when faced with problems where students are able to control the situation so that the situation returns to normal. This is accordingthe theory of Steadiness and personality. Steadiness is very well known for its consistency, it will do something to work / finish, more oriented to consistency rather than speed. Steadiness people are very capable of creating harmony in the workplace. The best 
contribution when being a true listener, patient, like to help and able to control the situation. Besides that they are able to work together with others in completing tasks. (SeptyaniMufida)

\subsection{Compliance}

From the results of the study showed that there were 23 students with Compliance personality, this meant that students with this personality in their learning process were able to complete assignments diligently, thoroughly and like to think complicatedly. There are 18 students with Compliance personality in everyday situations, where students in the learning process think critically and 21 students with Compliance personality when facing problems, which means that when students get into problems they are able to solve these problems well, diplomatically and professionally. In line with that the theory explains that individuals with Compliance personalities are diligent workers, focused on quality and accuracy. Characteristics of people with the nature of Compliance is very thorough and likes to think complicated. Individuals feel comfortable when in an environment that has clear work expectations. They like to do things that have a good impact. They are steadfast in their stance and choices so that they seem insistent. The positive qualities possessed by individuals with Compliance personality are critical thinking, meticulous, subtle approaches and analysis, well-planned plans, good problem solving skills, diplomatic, professional, and high loyalty.[10]

\section{Conclusion}

The findings from the research findings can be summarized as follows:

1. Students who have the type of Leader for the original personality are only 2 students and for situations in dealing with problems only amount to 3 people. This means that only 2 students who were studied had a Leader personality so it greatly influenced the learning process.

2. Students who have Influence type which are 16 students in daily situations, 14 students for original personality while for situations in dealing with problems are 24 students. This means that 14 students have influence personality, this means that the student is able to influence other friends to carry out learning activities well

3. Students with personality Steadinessthat have 32 students in everyday situations, 28 students for original personality and 19 students for situations in dealing with problems. This means that there are 28 students who have the personality of Steadiness so that students are able to do something to work / finish, more oriented to consistency rather than speed.

4. Students with Compliance personality (analysis) there are 18 people for everyday situations, 23 students for original personality and 21 students in situations facing problems. This means that there are 23 students who have Compliance personality, students with this personality are diligent workers, focused on quality and accuracy. Characteristics of people with the nature of Compliance is very thorough and likes to think complicated. 


\section{References}

[1] A. Sujanto, Psikologi Kepribadian. Jakarta: PT Bumi Aksaa, 2009.

[2] A. Ahmadi, Psikologi Perkembangan. Jakarta: PT Rineka Cipta, 2005.

[3] W. Angganantyo, "COPING RELIGIUS PADA KARYAWAN MUSLIM DITINJAU DARI TIPE KEPRIBADIAN,” JIPT, vol. Vol.02,No., pp. 50-61, 2014.

[4] C. K. E. Goni, H. Opod, and L. David, "Gambaran kepribadian berdasarkan tes Disc mahasiswa Fakultas Kedokteran Universitas Sam Ratulangi Manado semester 1 tahun 2016,” J. e-Biomedik, vol. 4, no. 2, 2016.

[5] E. Riadi, "Pengaruh Kepribadian, Kecerdasan Emosional, Dan Perilaku Kewargaan Organisasi Terhadap Kinerja Kepala Sekolah Menengah Atas Dan Kejuruan Di Kota Tangerang,” J. Manaj. Pendidik., pp. 432-441, 2017.

[6] N. Daulay, “済無No Title No Title,” J. Tarb., vol. 21, no. 2, pp. 402-421, 2014.

[7] M. S. Dewi Puri Astiti, S.Fil and M. E. P. Dr. Ni Made Swasti Wulanyani, S.Psi, "DISC Personality Style Analysis," 2015.

[8] A. Wardy, Analisis Profile Kepribadian Mengunakan Disc yang Mempengaruhi Penyelesaian Studi Mahasiswa Magister ManajemenKampus Kranggan. .

[9] Sugiyono, Metode Penelitian Pendidikan; Pendekatan Kuantitatif, Kualitatif, dan R\&D. Bandung: Alfabeta, 2013.

[10] S. Mufida, "Perbedaan Burn Out Ditinjau Dari Gaya Kepribadian Leader, Influence, Steadiness, dan Compliance," vol. 1, no. 1, pp. 47-55, 2012. 